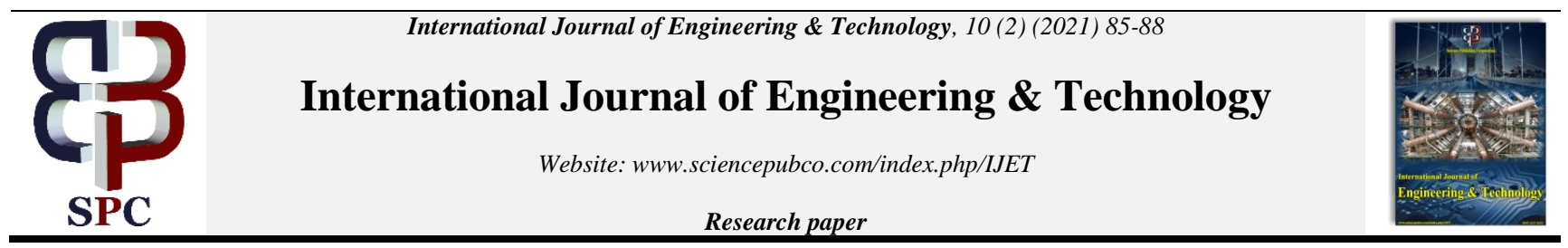

\title{
Importance of spindle speed in ring frame
}

\author{
Md. Redwanul Islam ${ }^{1}$ *, Amit Chakrabortty ${ }^{1}$, Joyjit Ghosh ${ }^{1}$, Tareq Iqbal ${ }^{2}$, Md. Tanvir Hossen ${ }^{3}$ \\ ${ }^{1}$ Lecturer, Department of Textile Engineering, Ahsanullah University of Science and Technology (AUST), Bangladesh \\ ${ }^{2}$ Lecturer, Department of Textile Engineering and Management, BGMEA University of Fashion and Technology, Bangladesh \\ ${ }^{3}$ Lecturer, Department of Textile Engineering, Jashore University of Science and Technology (JUST), Bangladesh \\ *Corresponding authorE-mail: redwan.tex@aust.edu
}

\begin{abstract}
In textile industries, spinning sector plays a vital role because this sector produces the main raw material for the textile industries which is known as yarn. So for getting good qualities garments, it is needed to ensure the good qualities yarn. There are many things which are responsible for producing good qualities yarn. Among these spindle speed is an important thing. One must have to change the spindle speed, when he changes the count. As every count has a particular spindle speed in which the production shows maximum production efficiency. Here we used five most commonly used yarn counts in the maximum factories. The counts are $15 \mathrm{Ne}, 20 \mathrm{Ne}, 25 \mathrm{Ne}, 30 \mathrm{Ne}$ and $40 \mathrm{Ne}$. We analyzed these counts with different speed and found that every count showed maximum efficiency at a particular spindle speed. The outcome of this paper is applicable in all types of ring frame machine, especially for producing single carded and combed yarn.
\end{abstract}

Keywords: Ring frame; RPM of Spindle; Spinning factory; Spindle; Yarn count.

\section{Introduction}

The productivity and efficiency of ring frame mostly depends on many factors like traveller, ring diameter, spindle speed etc [1-4]. When high speed spindle is used, it generates fly dust and causes fiber breakage. Hence there is a need fo selecting optimum speed of spindle, where one can get accurate production process as well as product quality [5-8]. On can get good qualities and breakage free production by selecting proper spindle speed [9].The identification of natural frequencies of the spindle because it's very difficult to measure the spindle speed when the spindle is moving at a high speed because there are a few sensors. For solving these problems some methods are used the modes are determined through a 3-step procedure. First, spindle modes are highlighted using the Frequency Domain Decomposition (FDD) technique, with a new formulation at the considered rotating speed. There are many counts variation in ring spinning system. Here I would like to introduce you about most commonly used yarn count like $15 \mathrm{Ne}, 20 \mathrm{Ne}, 25 \mathrm{Ne}, 30 \mathrm{Ne}$ and $40 \mathrm{Ne}$ [10]. Results show a good correlation between numerical and experiment-based identified frequencies. The identified spindle-tool modal properties during machining allow the numerical model to be considered as representative of the real dynamic properties of the system [11]. Ring spinning which uses the Ring frame is the main spinning system is used by 7 in every 8 mills to produce cotton yarns for fabric production by knitting and weaving factories 3 . The process of fibre to yarn conversion at the ring frame involves drafting, twisting roving of fibres and winding the spun yarn on the bobbin and is the costliest stage in the spinning process flow contributing $60 \%$ of the total cost of yarn production. Every factory wants to reduce the cost of their production for their profit as well as proper utilization of their natural sources [12].

\section{Materials and methods}

\subsection{Materials}

For this we use calculator, electric balance, and tachometer. Through the tachometer we measure the individual spindle speed and calculate them for comparing the reading value and electronic monitor value [13-15].

\subsection{Methods}

For this study we consider 1200 spindles and operate these and carefully monitor these for 7 days. We always try to maintain the all the spinning parameters properly and change only the spindle speed. The results of the work are discussed here with the practical data.

i) Efficiency of ring frame machine at 12000 RPM spindle Speed: 
Table 1: Efficiency Ring Frame Machine at 12000 RPM Spindle Speed

\begin{tabular}{ll}
\hline Yarn Count (Ne) when the spindle speed is 12000 RPM & Efficiency \% \\
\hline $15 \mathrm{Ne}$ & $95 \%$ \\
$20 \mathrm{Ne}$ & $88 \%$ \\
$25 \mathrm{Ne}$ & $80 \%$ \\
$30 \mathrm{Ne}$ & $70 \%$ \\
$40 \mathrm{Ne}$ & $55 \%$ \\
\hline
\end{tabular}

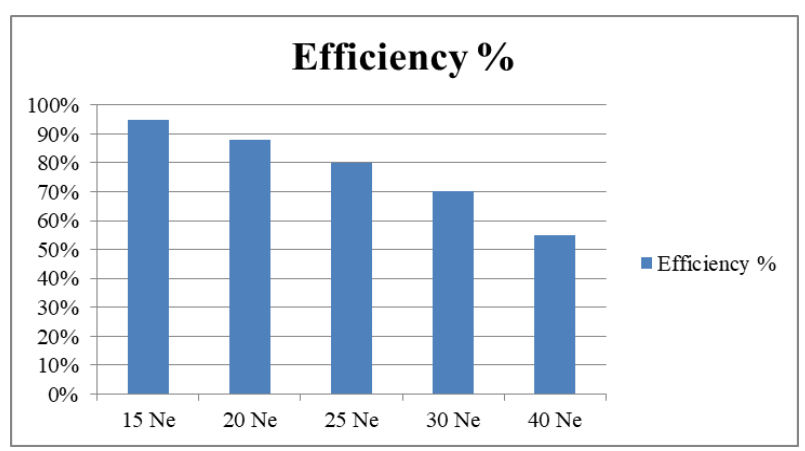

Fig. 1: Efficiency Ring Frame Machine at 12000 RPM Spindle Speed.

Fig. 1 shows the efficiency of ring frame is excellent (around 95\%) for $15 \mathrm{Ne}$ count when the spindle speed is $12000 \mathrm{RPM}$.

ii) Efficiency of ring frame machine at 13000 RPM spindle Speed:

Table 2: Efficiency Ring Frame Machine at 13000 RPM Spindle Speed

\begin{tabular}{ll}
\hline Yarn Count (Ne) when the spindle speed is 13000 RPM & Efficiency \% \\
\hline $15 \mathrm{Ne}$ & $88 \%$ \\
$20 \mathrm{Ne}$ & $96 \%$ \\
$25 \mathrm{Ne}$ & $85 \%$ \\
$30 \mathrm{Ne}$ & $73 \%$ \\
$40 \mathrm{Ne}$ & $60 \%$ \\
\hline
\end{tabular}

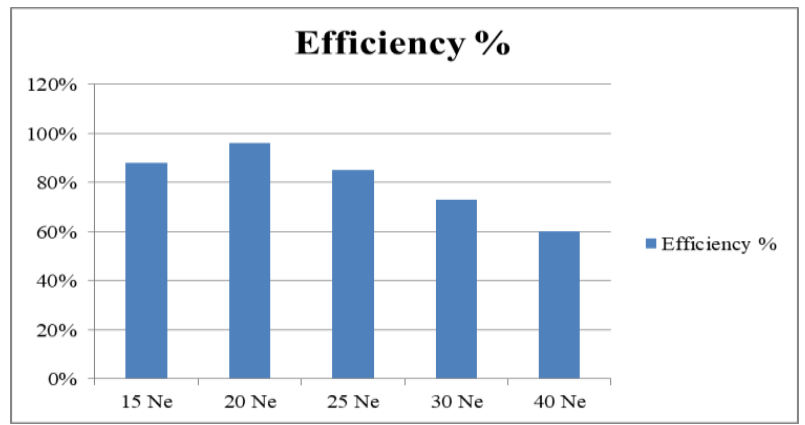

Fig. 2: Efficiency Ring Frame Machine at 13000 RPM Spindle Speed.

Fig. 2 shows the efficiency of ring frame is excellent (around 96\%) for $20 \mathrm{Ne}$ count when the spindle speed is $13000 \mathrm{RPM}$.

iii) Efficiency of ring frame machine at $14000 \mathrm{RPM}$ spindle Speed:

Table 3: Efficiency Ring Frame Machine at 14000 RPM Spindle Speed

\begin{tabular}{ll}
\hline Yarn Count (Ne) when the spindle speed is 14000 RPM & Efficiency \% \\
\hline $15 \mathrm{Ne}$ & $78 \%$ \\
$20 \mathrm{Ne}$ & $85 \%$ \\
$25 \mathrm{Ne}$ & $95 \%$ \\
$30 \mathrm{Ne}$ & $82 \%$ \\
$40 \mathrm{Ne}$ & $75 \%$ \\
\hline
\end{tabular}

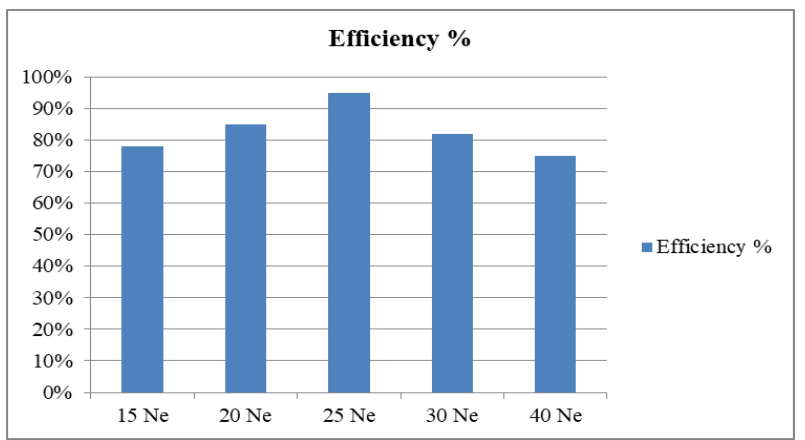

Fig. 3: Efficiency Ring Frame Machine at 14000 RPM Spindle Speed.

Fig. 3 shows the efficiency of ring frame is excellent (around 95\%) for $25 \mathrm{Ne}$ count when the spindle speed is 14000 RPM.

iv) Efficiency of ring frame machine at 16000 RPM spindle Speed: 
Table 4: Efficiency Ring Frame Machine at 16000 RPM Spindle Speed

\begin{tabular}{ll}
\hline Yarn Count (Ne) when the spindle speed is 16000 RPM & Efficiency \% \\
\hline $15 \mathrm{Ne}$ & $65 \%$ \\
$20 \mathrm{Ne}$ & $80 \%$ \\
$25 \mathrm{Ne}$ & $85 \%$ \\
$30 \mathrm{Ne}$ & $98 \%$ \\
$40 \mathrm{Ne}$ & $88 \%$ \\
\hline
\end{tabular}

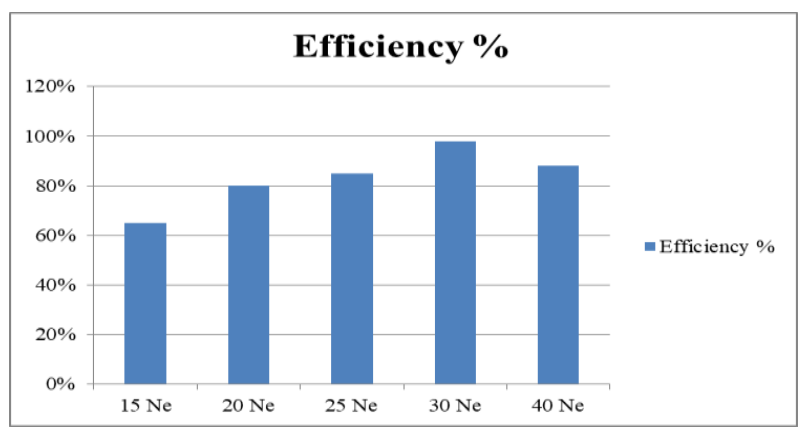

Fig. 4: Efficiency Ring Frame Machine at 16000 RPM Spindle Speed.

Fig. 4 shows the efficiency of ring frame is excellent (around 98\%) for $30 \mathrm{Ne}$ count when the spindle speed is 16000 RPM.

v) Efficiency of ring frame machine at 17000 RPM spindle Speed:

Table 5: Efficiency Ring Frame Machine at 17000 RPM Spindle Speed

\begin{tabular}{ll}
\hline Yarn Count (Ne) when the spindle speed is 17000 RPM & Efficiency \% \\
\hline $15 \mathrm{Ne}$ & $55 \%$ \\
$20 \mathrm{Ne}$ & $70 \%$ \\
$25 \mathrm{Ne}$ & $80 \%$ \\
$30 \mathrm{Ne}$ & $90 \%$ \\
$40 \mathrm{Ne}$ & $95 \%$ \\
\hline
\end{tabular}

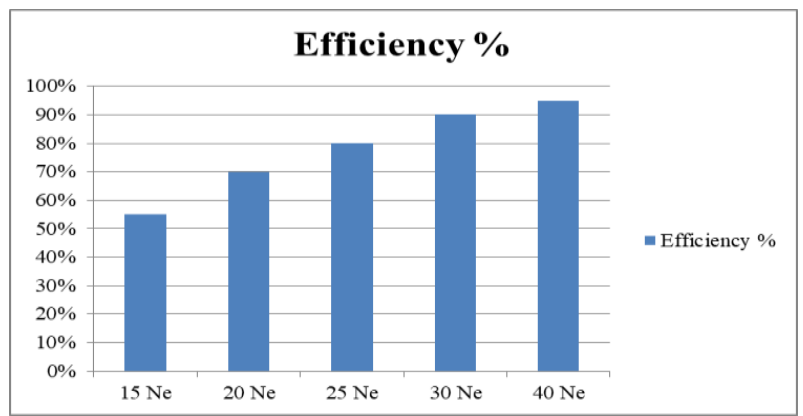

Fig. 5: Efficiency Ring Frame Machine at 17000 RPM Spindle Speed.

Fig. 5 shows the efficiency of ring frame is excellent (around 95\%) for $40 \mathrm{Ne}$ count when the spindle speed is $17000 \mathrm{RPM}$.

From the above values we can see that the speed of spindle of ring frame varies when we change the count. So it is necessary to consider the spindle speed on the basis of yarn count.

We should also consider the idle spindle in the ring frame cause this plays a vital role in the production. Many properties of yarn like hairiness, imperfections, tenacity and elongation produced different spindle speed of the ring frame machine. The hairiness and imperfections also increased when we didn't control the spindle speed properly [16]. The developing country like ours economy $80 \%$ depends on the Textile sector and Spinning is the first textile sector. There are 425 spinning mills established in Bangladesh which provide the raw materials yarn to the textile sector. The production of Spinning Mills depends on the production rate of the spindle in ring frame. There are around 12410000 spindles in 425 spinning mills in Bangladesh [19]. The quality of the ring yarn depends on the spindle speed. So the effect of spindle speed of ring frame on yarn quality is very important. In this research we want to highlight the importance of spindle speed [17]. We know that the higher speed of spindle can break the yarn. So we need to maintain the accurate speed [18].

\section{Research limitations}

Data for the study was collected from Yasmin spinning mills Ltd. Another limitation is we didn't monitor the spindle speed as well as the production in the night shift.

\section{Conclusion}

The yarn count $15 \mathrm{Ne}, 20 \mathrm{Ne}, 25 \mathrm{Ne}, 30 \mathrm{Ne}$ and $40 \mathrm{Ne}$ shows around 95\% efficiency when the spindle speed is at $12000 \mathrm{rpm}, 13000 \mathrm{rpm}$, $14000 \mathrm{rpm}, 16000 \mathrm{rpm}$ and $17000 \mathrm{rpm}$ respectively. By using these accurate values for particular yarn count, the speed of production and the quality of yarn can be increased. If factory applies those parameters properly, it can attain better outcome. As Bangladesh imports mostly from other countries, it can't ignore its own good quality yarn production. 


\section{Acknowledgement}

The author thanks NOMAN Group and general manager Md. Mazed for supporting the research work.

\section{References}

[1] Miao M, How YL, Ho SY. Influence of spinning parameters on core yarn sheath slippage and other properties. Textile Research Journal. 1996 Nov;66(11):676-84. https://doi.org/10.1177/004051759606601102.

[2] Patil MJ, Kolte PP, Gulhane MS. Effect of Spindle Speed of Ring frame on yarn quality. IPI. 2019;442(319):232. https://www.researchgate.net/profile/PrafullKolte/publication/330305159_Effect_of_Spindle_Speed_of_Ring_frame_on_yarn_quality/links/5c3811eb458515a4c71c9baa/Effect-ofSpindle-Speed-of-Ring-frame-on-yarn-quality.pdf

[3] Ahmad N, Hossen J, Ali SM. Improvement of overall equipment efficiency of ring frame through total productive maintenance: a textile case. The international journal of advanced manufacturing technology. 2018 Jan;94(1):239-56. https://doi.org/10.1007/s00170-017-0783-2

[4] Hossain M, Telke C, Abdkader A, Cherif C, Beitelschmidt M. Mathematical modeling of the dynamic yarn path depending on spindle speed in a ring spinning process. Textile Research Journal. 2016 Jul;86(11):1180-90. https://doi.org/10.1177/0040517515606355.

[5] Schlafhorst, Preparation of Linen Fibres and Their Processing in Ring and Rotor Spinning, Manchenglabatch, Germany, 1995, pp. 33 https://doi.org/10.2174/1876520301104010007.

[6] Akankwasa NT, Wang J, Zhang Y. Study of optimum spinning parameters for production of T-400/cotton core spun yarn by ring spinning. The Journal of the Textile Institute. 2016 Apr 2;107(4):504-11. https://doi.org/10.1080/00405000.2015.1045254

[7] Ishtiaque SM, Rengasamy RS, Ghosh A. Optimization of ring frame process parameters for better yam quality and production. http://nopr.niscair.res.in/handle/123456789/24624.

[8] Ratnam TV. Optimization of Spindle Speeds in Ring Frames. http://nopr.niscair.res.in/handle/123456789/24624.

[9] Lawal AS, Nkeonye PO, Anandjiwala RD. Influence of spindle speed on yarn quality of Flax/Cotton blend. The Open Textile Journal. 2011;4:7-12. https://doi.org/10.2174/1876520301104010007.

[10] Üreyen ME, Kadoglu H. Regressional estimation of ring cotton yarn properties from HVI fiber properties. Textile Research Journal. 2006 May;76(5):360-6. https://doi.org/10.1177/0040517506062262.

[11] Gagnol V, Le TP, Ray P. Modal identification of spindle-tool unit in high-speed machining. Mechanical Systems and Signal Processing. 2011 Oct 1;25(7):2388-98. https://doi.org/10.1016/i.ymssp.2011.02.019.

[12] Musyoki JK, Muchiri PN, Keraita JN. Improvement of Ring Frame Spindle Utilization in Cotton Short Staple Spinning: A Case Study of a Cotton Spinning Mill. http://41.89.227.156:8080/xmlui/handle/123456789/982.

[13] Tunggal TP, Kirana LA, Arfianto AZ, Helmy ET, Waseel F. The design of tachometer contact and non-contact using microcontroller. Journal of Robotics and Control (JRC). 2020 Feb 26;1(3):65-9. https://doi.org/10.18196/jrc.1315.

[14] Huang H, Baddour N, Liang M. A method for tachometer-free and resampling-free bearing fault diagnostics under time-varying speed conditions. Measurement. 2019 Feb 1;134:101-17. https://doi.org/10.1016/j.measurement.2018.10.074.

[15] Sharma V, Parey A. Frequency domain averaging based experimental evaluation of gear fault without tachometer for fluctuating speed conditions Mechanical Systems and Signal Processing. 2017 Feb 15;85:278-95. https://doi.org/10.1016/j.ymssp.2016.08.015.

[16] Patil MJ, Kolte PP, Gulhane MS. Effect of Spindle Speed of Ring frame on yarn quality. IPI. 2019;442(319):232. https://www.researchgate.net/profile/PrafullKolte/publication/330305159_Effect_of_Spindle_Speed_of_Ring_frame_on_yarn_quality/links/5c3811eb458515a4c71c9baa/Effect-ofSpindle-Speed-of-Ring-frame-on-yarn-quality.pdf

[17] J. D. Patil, P. P. Kolte, and S. S. Gulhane, 'Effect of Spindle Speed of Ring Frame on Yarn Quality', no. January, 2019. https://www.researchgate.net/profile/PrafullKolte/publication/330305159_Effect_of_Spindle_Speed_of_Ring_frame_on_yarn_quality/links/5c3811eb458515a4c71c9baa/Effect-of-Spindle-Speed-of-Ring-frame-on-yarn-quality.pdf

[18] K. P. Chellamani, K. Gnanasekar, and S. Karthikeyan, 'Effect of spindle speed on end breakage and yarn quality while using lower package size', vol. 20, no. June, pp. 83-85, 1995. http://nopr.niscair.res.in/handle/123456789/32304

[19] H. Tanvir, 'Cotton and Products Annual_Dhaka_Bangladesh', Global Agricultural Information Netwok (GAIN), Dhaka, 2018. https://d1wqtxts1xzle7.cloudfront.net/. 